\title{
Characterisation of Class 1 Integron among Escherichia coli Isolated from Mansoura University Hospitals in Egypt
}

\author{
Mohamed Mohamed Adel El-Sokkary*, Eman Salama Abdelmegeed \\ Microbiology Department, Faculty of Pharmacy, Mansoura University, Mansoura, Egypt \\ Email: ${ }^{*}$ m_elsokkary2022@yahoo.com
}

Received 19 March 2015; accepted 20 April 2015; published 24 April 2015

Copyright (C) 2015 by authors and Scientific Research Publishing Inc.

This work is licensed under the Creative Commons Attribution International License (CC BY). http://creativecommons.org/licenses/by/4.0/

(c) (i) Open Access

\section{Abstract}

Extensive use of antibacterials in clinical practice has been associated with increasing frequency of multi-resistant $E$. coli strains. Genetic elements such as Class 1 integrons have an important role in resistance development. In the current study, a total of $84 \mathrm{E}$. coli clinical isolates from Mansoura hospitals patients in Egypt were screened for antibacterial susceptibility against 12 different antibacterials. High resistance rates were identified for Ampicillin (92.9\%) and sulfamethoxazole/ trimethoprim (84.5\%). Class 1 integron was investigated in E. coli isolates by PCR. As a result, Class 1 integron was identified in $51.2 \%$ of these isolates. The contents of amplified integron varriable regions, were digested by Alu I restriction endonuclease. Cluster analysis of Class 1 integron digested varriable regions revealed that RFLP digested fragments generated could be classified into 9 different patterns, namely A, B, C, D, E, F, G, H and I. The most prevalent genotype was identifed in Group D. PCR and sequencing were used for detection of antimicrobial resistance genes harbored in integrons of Group D. As a result, main phylogenetic group identified harbored integron cassette carrying resistance gene for two antimicrobial groups namely aminoglycoside and trimethoprim. Multiresistance profiles in Group D exhibited association between antimicrobial resistance and integron presence. These findings suggest that the strategy for treatment of patients with $E$. coli infections needs to be revised. Furthermore, the high prevalence of Class 1 integron carrying gene confirms the importance of integron-mediated antimicrobial gene cassettes.

\section{Keywords}

Integron, Antimicrobial Resistance, E. coli, RFLP

\footnotetext{
${ }^{*}$ Corresponding author.
}

How to cite this paper: El-Sokkary, M.M.A. and Abdelmegeed, E.S. (2015) Characterisation of Class 1 Integron among Escherichia coli Isolated from Mansoura University Hospitals in Egypt. Advances in Microbiology, 5, 269-277. 


\section{Introduction}

The level of antibiotic resistance among hospital and community-acquired isolates has steadily increased and has become a major global health problem. E. coli is responsible for numerous diseases in humans and animals [1]. The rapid emergence of antibiotic resistance among bacteria is mainly due to the spread of antibiotic resistance genes by horizontal gene transfer [2]. The dissemination of numerous antimicrobial resistance genes among bacteria has become an increasingly serious problem, which got more attention worldwide in recent decade [3] [4].

In Enterobacteriaceae, conjugative plasmids and transposons are considered as the major agents of spread and maintenance of multidrug resistance genes within species and between different species. In addition, resistance genes can be integrated into DNA elements designated as integrons [5]. Although integrons by themselves are not mobile but due to their presence in plasmids and transposons, they can be transferred horizontally [6] [7].

Multi-drug resistance in Enterobacteriaceae is strongly associated with integrons which confers resistance to different antimicrobial agents [8]. Several gene cassettes may be present in one integron which leads to multiple drug resistance in bacteria [9]. Classes 1 and 2 integrons are the most frequently detected in many bacterial species carrying different arrangements of gene determinants associated with antimicrobial resistance [10]. The main components of each integron include integrase gene encoding a site-specific recombinase, an insertion site recognized by the integrase and a variable region in which gene cassettes can be inserted [11].

The rates of drug resistant clones of E. coli have been continously increasing over the last few years [1]. There are an increasing number of publications describing the occurrence of integrons in both human and animal bacteria, especially in E. coli. The distribution of Class 1 integron in $E$. coli has been previously studied in India [12], Germany [13], Korea [14], USA [15], Iran [16] and Sudan [17]. These studies have established a strong association between the presence of integrons and antimicrobial resistance. However, comparative analysis through molecular typing of Class 1 integron based on RFLP analysis is not extensively reported especially in Egypian hospitals. The aims of this study were to identify the relative occurrence of Class 1 type of integron in different Mansoura hospitals in Egypt, to type these fragments into distinguishable clusters and to identify the component of integron cluster including the majority of our E. coli strains.

\section{Materials and Methods}

\subsection{Bacterial Strains}

Eighty four clinical E. coli isolates were collected from Mansoura University hospitals namely: Emergency Hospital, Urology and Nephrology Center and Mansoura Specialized Medical Hospital in Dakahlia governorate, Egypt during March 2013 to February 2014. The isolates were collected from urine (53), wound (20) and sputum (11) samples. These isolates were identified using standard biotyping methods [18].

\subsection{Antibiotic Susceptibility Testing}

Susceptibility to fifteen antimicrobials was determined under the recommendations of the Clinical laboratory Standards Institute (CLSI, formerly NCCLS) guidelines [19]. Inhibition zone diameters were interpreted in accordance with CLSI guideline using WHONET software version 5.3. The discs used in this study are: tobramycin $(10 \mu \mathrm{g})$, gentamicin $(10 \mu \mathrm{g})$, cefotaxime (30 $\mu \mathrm{g})$, ceftriaxone (30 $\mu \mathrm{g})$, imipenem $(10 \mu \mathrm{g})$, ceftazidime (30 $\mu \mathrm{g})$, ampicillin $(10 \mu \mathrm{g})$, norfloxacin $(5 \mu \mathrm{g})$, ciprofloxacin $(5 \mu \mathrm{g})$, levofloxacin $(5 \mu \mathrm{g})$, sulfamethoxazole/trimethoprim(23.75/1.25) and amikacin (30 $\mu \mathrm{g})$ (Oxoid).

\subsection{PCR-Detection of Class 1 Integron in the Isolates of $E$. coli}

Screening for integrons was carried out by polymerase chain reaction (PCR) amplification of IntM1 using the primer sets listed in Table 1. Crude lysates of the bacterial cells were prepared by transferring bacterial isolates to distilled water in Eppendorf tubes and then boiling for $10 \mathrm{~min}$. The crude bacterial lysates were used directly in the PCR reaction as a source for the template DNA. The PCR reaction mixture included $0.5 \mu \mathrm{M}$ of each primer (BIONEER Seol South Korea), 1 U Taq polymerase (Thermo scientific Dream Taq Green DNA polymerase primers USA), $1.5 \mathrm{mM} \mathrm{MgCl} 2,0.2 \mathrm{mM}$ dNTPs, $5 \mu$ of template DNA and nuclease free water to complete the reaction volume $(25 \mu \mathrm{l})$. PCR amplification was performed in Techne Progene thermocycler under the following conditions: initial denaturation at $95^{\circ} \mathrm{C}$ for 3 min, followed by 40 cycles of denaturation at $95^{\circ} \mathrm{C}$ for $30 \mathrm{~s}$, an- 
Table 1. Primers used for amplification of Class 1 integrase gene and its variable regions.

\begin{tabular}{cccccc}
\hline Primer & Sequence & Size of Amplicon (bp) & Targets & Gen Bank Number & References \\
\hline IntM1-U & 5'-ACGAGCGCAAGGTTTCGGT-3' & 565 & Inti1 & AF550415 & {$[31]$} \\
IntM1-D & 5'-GAAAGGTCTGGTCATACATG-3' & & & & \\
5'-CS & 5'-GGCATACAAGCAGCAAGC-3' & Variable & $\begin{array}{c}\text { Gene Cassette(s) of } \\
\text { Class 1 Integron }\end{array}$ & U12338 & {$[32]$} \\
3'-CS & 5'-AAGCAGACTTGACCTGAT-3' & & & \\
\hline
\end{tabular}

nealing at $62^{\circ} \mathrm{C}$ for $30 \mathrm{~s}$, and extension at $72^{\circ} \mathrm{C}$ for $1 \mathrm{~min}$. Final extension was carried out at $72^{\circ} \mathrm{C}$ for $5 \mathrm{~min}$. PCR products were analyzed by agarose gel electrophoresis on $1 \%$ agarose gel (Sigma-Aldrich, USA) and visualized by ethidium bromide staining (Sigma-Aldrich, USA). All tests were twicely done for verification of results.

\subsection{Characterization of the Variable Region of Class 1 Integrons}

Amplification of the variable region of Class 1 integrons was performed using two primers CS'3 and CS'5. The reaction mixture was prepared as described previously. PCR reactions began with 10 min of primary denaturation at $94^{\circ} \mathrm{C}$ followed by 40 cycles of $94^{\circ} \mathrm{C}$ for $30 \mathrm{~s}, 50^{\circ} \mathrm{C}$ for $30 \mathrm{~s}$ and finally $72^{\circ} \mathrm{C}$ for $30 \mathrm{~s}$. Final extension was performed at $72^{\circ} \mathrm{C}$ for $5 \mathrm{~min}$.

\subsection{Restriction Fragments Length Polymorphism (RFLP)}

To detect variation in size of the amplified integron variable regions, RFLP analysis was performed using Alu I (Fermentas, Lithuania) as digesting restriction endonuclease. Briefly, each $30 \mu \mathrm{l}$ of the restriction mixture contained $1 \mu \mathrm{l}(20 \mathrm{U})$ of enzyme, $7 \mu \mathrm{l}$ of PCR-amplified product, $2 \mu \mathrm{l}$ of enzyme buffer and $20 \mu \mathrm{l}$ of double-distilled water. According to manufacturer's guidelines, restriction mixtures were incubated at $37^{\circ} \mathrm{C}$ for one hour and the digested PCR products were electrophoresed on $2 \%$ agarose gel at $90 \mathrm{~V}$. Cluster analysis for analyzing the digested fragment was performed using the un-weighted pair-group method with average linkages (UPGMA).

\subsection{Determination of the Gene Sequence of Integron in Most Common Pattern}

Amplified gene fragments were purified from one strain in the most common RFLP pattern D using the PCR Purification Kit (MEGA quick-spin fragment DNA purification INTRON biotechnology, Sangdaewon-dong, Korea) for subsequent Sequencing. Purified PCR products were used as a template in sequencing reactions carried out with the ABI PRISM ${ }^{\circledR}$ BigDye Terminator Cycle Sequencing Ready Reaction Kit (Applied Bio-Systems, Foster City, USA). The reaction mixtures were analysed on an ABI 3730 DNA analyzer (Applied Biosystems, Foster City, USA). Amplicons were sequenced on both strands and the predicted peptide sequences were analyzed by the online BLAST of the NCBI website software (http://www.ncbi.nlm.nih.gov/BLAST/).

\section{Results}

\subsection{Antibiotic Susceptibility Testing}

Among the drugs under the study, ampicillin has the least antimicrobial effect as $92.9 \%$ of the total isolates were resistant. On the other hand, all E. coli isolates were sensitive to imipenem. In addition, the highest resistance rate was recorded to sulfamethoxazole/trimethoprim (84.5\%), ceftriaxone (81\%), ceftazidime (78.5\%), norfloxacin and ciprofloxacin (71.4\%), levofloxacin (60.7\%), tobramycin (57\%), Gentamicin (53.6\%) and cefotaxime (46.4\%). In contrast, resistance to amikacin was less common but was seen in only $20.2 \%$ of the isolates.

\subsection{Identification and Characterization of Gene Cassette of Class 1 Integron Fragments}

Class 1 integron was detected in 43 (51.2\%) isolates. Figure 1 shows the results of amplification of Class 1 integron in some starins. These isolates were characterized through DNA amplification of the variable region.

A 2000 bp PCR product was obtained from 10 isolates, 1500 bp amplicon was obtained from 10 isolates, 6 


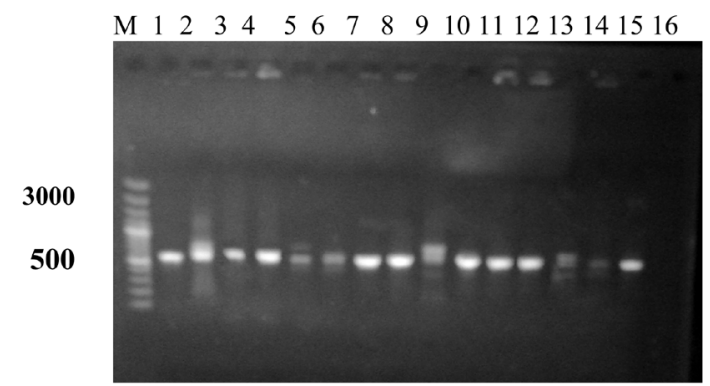

Figure 1. Agarose gel electrophoresis of Class 1 integron gene. Lane $\mathrm{M}$ is 100 bp plus ladder molecular weight marker. Lanes 1 to 15 were amplicons of intMI gene for $E$. coli isolates No. 3, 12, 20, 26, 31, 33, 41, 42, 50, 53, $55,57,60,61,62$. Lane 16 is a negative control.

isolates gave a 700 bp PCR product, an amplicon of 400 bp was obtained from 9 isolates, 800 bp amplicon was obtained from 4 isolates. 3 isolates gave $1800 \mathrm{bp}$ and amplicon of $500 \mathrm{bp}$ was obtained from one isolate.

For further classification of Class 1 integron fragments, the amplicons of the integron varriable region IVRs, were digested by Alu I restriction endonuclease (Figure 2). To evaluate the similarity of these E. coli isolates, the fingerprints were recorded, followed by computerized analysis of the acquired data. DNA relatedness, based on the UPGMA software, is shown in Figure 3. Cluster analysis of digested fragments generated 9 different patterns, namely A, B, C, D, E, F, G, H and I. In each group, all restriction patterns showing $100 \%$ similarity were assigned to the same group. Group A included two isolates from urine 62 and 26.6 urine isolates 27, 79, 3, 22, 57 and 12 in addition to two wound isolates 74 and 78 were classified under Group B. Group C included one sputum isolate 45 and one urine isolate 33. Nine urine isolates $6,8,39,76,31,54,20,50,15$ and 3 wound isolates 24, 53 and 55 were clustered in Group D. Group E included one wound 41 and one urine 29. Group F included one wound 42 and one urine 60. Three urine isolates 36, 64 and 13 were assigned under Group G. Group $\mathrm{H}$ included two urine isolates 35 and 40. Finally, Group I included one wound isolate 18 and two urine isolates 61 and 70.

\subsection{Identification of Gene Sequence of Mostly Identified Cluster}

The most prevalent restriction pattern in IVRs is identified in Group D which included 9 urine and 3 wound isolates. DNA of Class 1 integron fragment of E. coli isolates in group D was subjected to further analysis for identification of the gene sequence of such cassette.

DNA sequencing analysis indicated that these isolates harbored genes were (dfrA17)-(aadA5) which encode dihydrofolate reductase and aminoglycosides adenyltransferase, conferring resistance to trimethoprim and aminoglycosides respectively (Figure 4).

\section{Discussion}

Antimicrobial resistance in human pathogens has become a major public health issue [20]. Integrons are known to be associated with multi-drug resistance, especially Class 1 integron, which is widely distributed among Gramnegative bacteria. They have been identified as the primary source of resistance genes, and were suspected to serve as reservoirs of antimicrobial resistance genes within microbial populations [21] [22]. In this study, ampicillin has the least antimicrobial effect as $92.9 \%$ of the tested isolates were resistant to it. In addition, most of $E$. coli isolates were resistant to ceftazidime, ceftriaxone, norfloxacin, ciprofloxacin, levofloxacin, tobramycin, gentamicin and trimethoprim/sulfamethoxazole. Resistance to imipenem was not observed in these isolates. High sensitivity of E. coli strains to imipenem has also been reported in previous studies [12] [23]-[25]. It seems that this antibiotic can serve as drug of choice for treatment of multiresistant $E$. coli infections.

High incidence of multi-drug resistant (MDR) strains was also detected among the E. coli isolates in this study, where $84 \%$ of the isolates were resistant to at least three of the tested antimicrobials. The level of multidrug resistance among $E$. coli varies from country to country. In previuos reports, multidrug resistance was identified as 7.1\% in 2000 in USA [25] [26] and 42\% of the isolates in 2006 in Solvenia [13]. Such multidrug resistance has serious implications for the empirical therapy of infections caused by $E$. coli and for the possible co- 
A

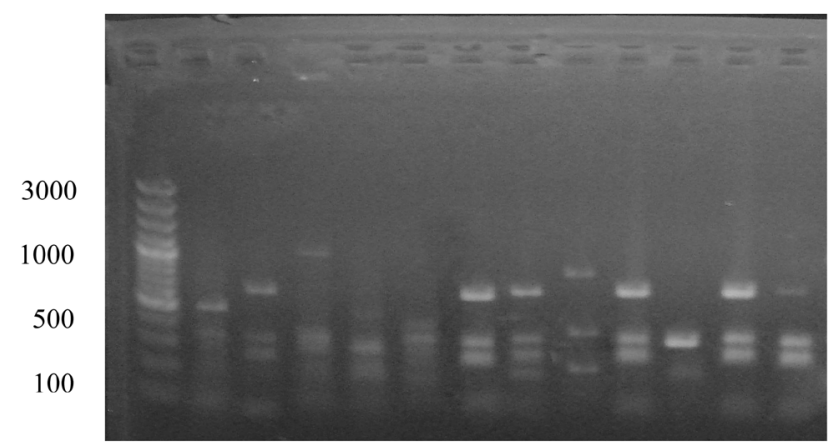

B
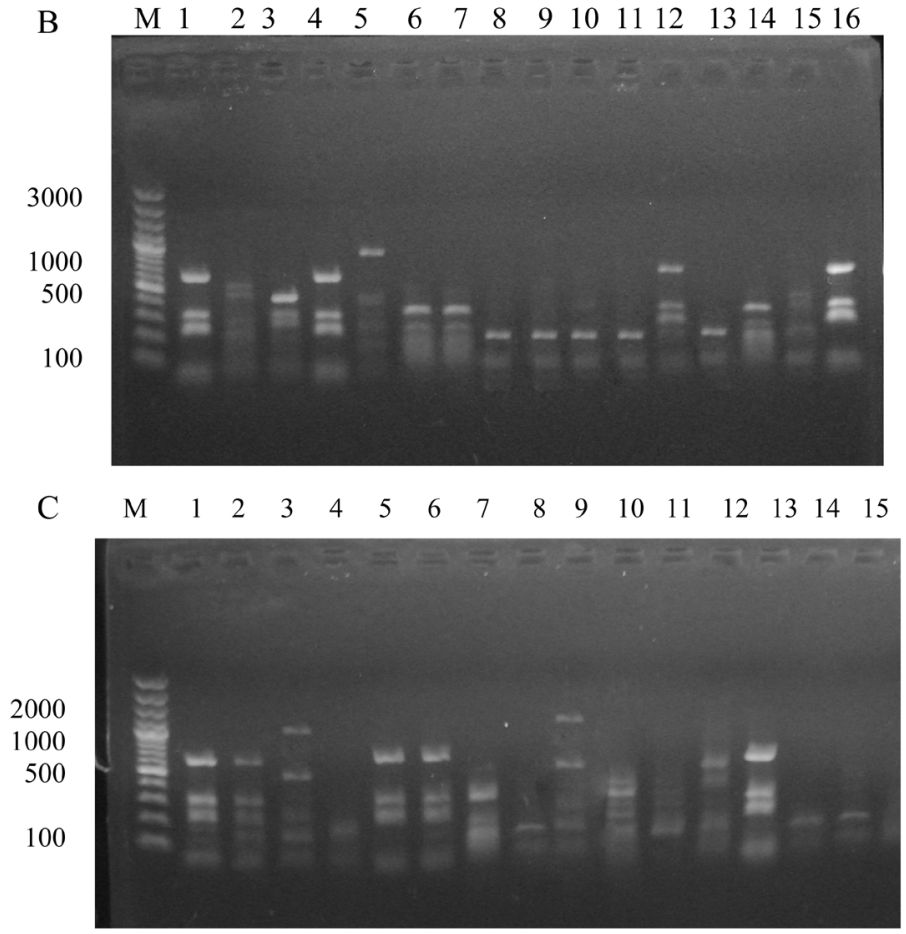

Figure 2. Agarose gel electrophoresis of the Class 1 integron variable region after restriction. Lane $\mathrm{M}$ was $100 \mathrm{bp}$ plus ladder molecular weight marker. A. Lanes 1 to 12 were amplicons of Class 1 integron variable region from E. coli isolates No. 46, 6, 43, 69, 40, 16, 24, 17, 39, 84, 76, 29 respectively; B. Lanes 1 to 16 were amplicones of Class 1 integron variable region from $E$. coli isolates No. 54, 45, 35, 15, 18, 64, 36, 27, 74, 79, 3, 8, 22, 13, 33, 31 respectively; C. Lanes 1 to 15 were amplicons of Class 1 integron variable region from $E$. coli isolates No. 55, 41, 61, 26, 53, 50, 60, $57,70,42,62,67,20,78,12$ respectively.

selection of antimicrobial resistance mediated by multidrug resistance mediated by multidrug resistance plasmids. Integrons are usually located within transposons or conjugative plasmids. These genetic elements are capable of capturing genes encoding antimicrobial resistance by site-specific recombination system. In addition, they contribute to the acquisition of new genes in bacteria. Class 1 integron is prevalent on plasmids in both Gram-positive and especially in Gram-negative bacteria [27]. The presence of Class 1 integron was investigated in bacteria isolated from animals, water, human stools [28]. Previous studies have clearly illustrated the wide ditribution of class1 integrons among bacterial isolates in Europe [29], the USA, Africa [30] and Asia [12]. In our study, Class 1 integron was identified in 43 out of $84 \mathrm{E}$. coli isolates which were collected from clinical patients. Other reports revealed the prevalence of Class 1 integron in clinical E. coli isolates is: $85.6 \%$ in China [31], 40.6\% in Sudan [17], 22.05\% in northern west of Iran 


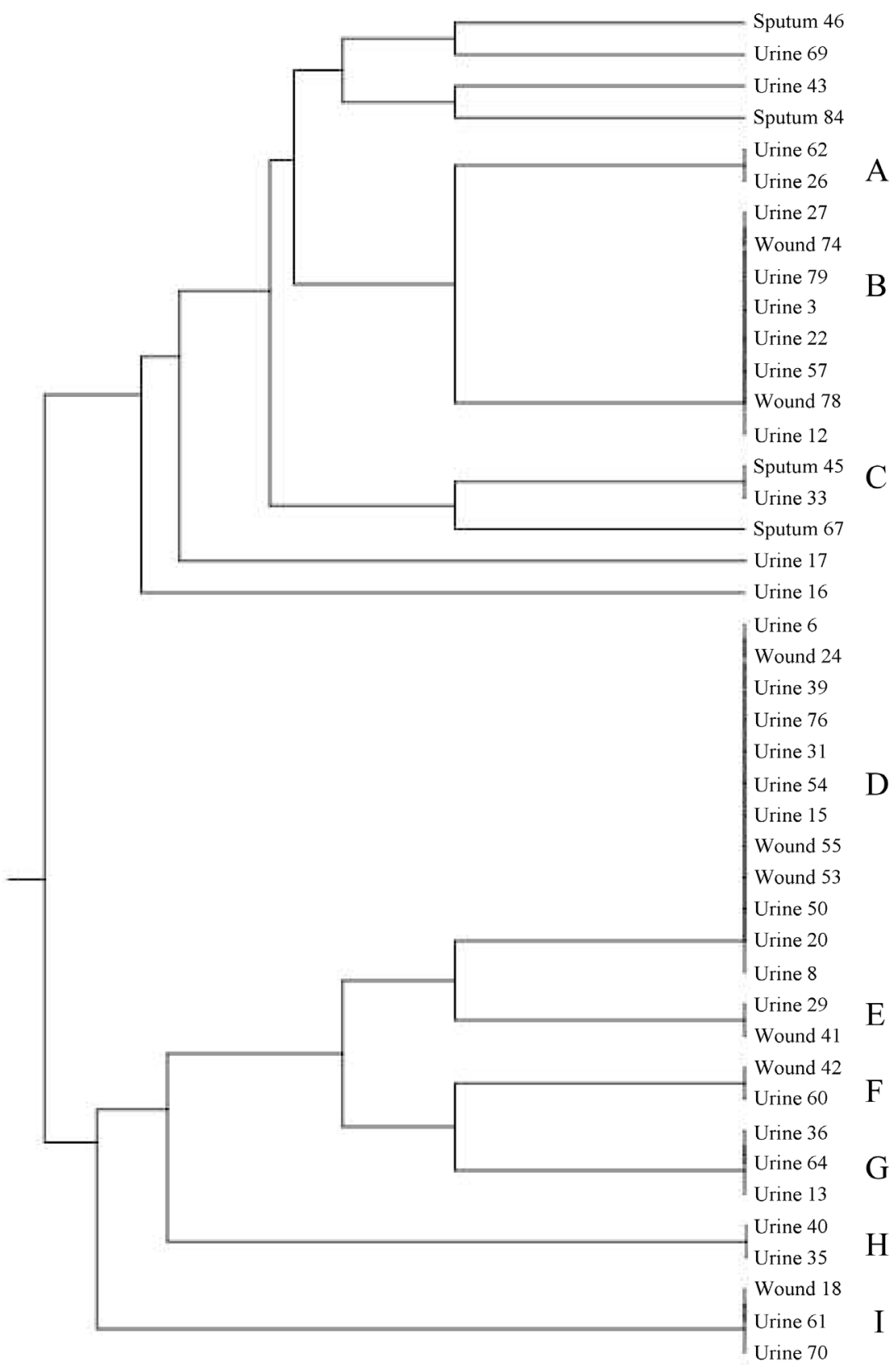

Figure 3. Dendrogram analysis of DNA fingerprinting obtained from Class 1 integron amplified IVRs fragments digested by Alu I restriction endonuclease in E. coli strains.

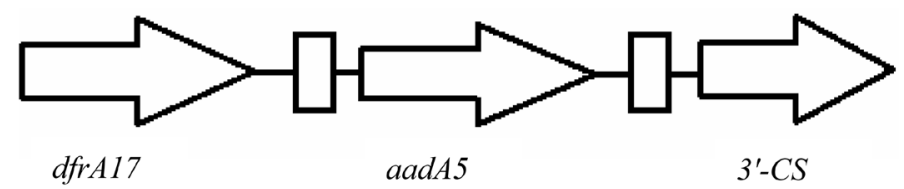

Figure 4. Schematic representation of the most predominant Class 1 integron pattern from $E$. coli isolates. These integrons had approximate sizes $2 \mathrm{~kb}$. Arrows indicate the direction of transcription.

[16]. In the isolated strains Class 1 integron was associated with resistance to certain antibiotics (Table 2). By DNA amplification of the variable region, 43 isolates were found to carry detectable Class 1-related integrons, 
Table 2. Antibiotic sensitivity of $E$. coli strains and correlation with integrons.

\begin{tabular}{ccc}
\hline Antibiotic & Total resistant n (\%) & Positive Class I integron n (\%) \\
\hline Ampicillin & $78(92.9 \%)$ & $42(53.8 \%)$ \\
Ceftazidime & $66(78.5 \%)$ & $35(53 \%)$ \\
Ceftriaxone & $68(81 \%)$ & $35(51.5 \%)$ \\
Cefotaxime & $39(46.4 \%)$ & $30(77 \%)$ \\
Norfloxacin & $60(71.4 \%)$ & $34(56.7 \%)$ \\
Ciprofloxacin & $60(71.4 \%)$ & $34(56.7 \%)$ \\
Levofloxacin & $51(60.7 \%)$ & $34(66.7 \%)$ \\
Tobramycin & $48(57 \%)$ & $29(60.4 \%)$ \\
Gentamicin & $45(53.6 \%)$ & $27(60 \%)$ \\
Amikacin & $17(20.2 \%)$ & $15(88.2 \%)$ \\
Sulfamethoxazole/Trimethoprim & $71(84.5 \%)$ & $32(45.1 \%)$ \\
Imipenem & 0 & 0 \\
\hline
\end{tabular}

showing the existence of amplicons of 2000 bp, 1800 bp, 1500 bp, 800 bp, 700 bp, 500 bp and 400 bp in 10, 3, 10, 4, 6, 1 and 9 isolates respectively. RFLP digested fragments which are generated could be classified into 9 different patterns, namely A, B, C, D, E, F, G, H and I. Most identified patterns were Group B and Group D. Group B included 6 urine isolates: 27, 79, 3, 22, 57 and 12 in addition to two wound isolates 74 and 78. However, 9 urine isolates : 6, 8, 39, 76, 31, 54, 20, 50, 15 and 3 wound isolates 24, 53 and 55 were classified under Group D. The dfrA17-aadA5 cassette was detected in Group D E. coli strains conferring resistance to trimethoprim and aminoglycosides. Previous studies demonstrated that this cassette was identified in isolates from different sources [32]-[36], which may indicate that the dfrA17-aadA5 array can disseminate by self-transferable plasmids in humans or animals. It was believed that the spread of trimethoprim resistance genes in clinical isolates is mostly associated with insertion of gene cassettes into integrons [37]. In our study, trimethoprim and gentamicin resistances were indicated in different $d f r A 17$-aadA5 carrying E. coli isolates. However, other antibiotic resistances which are not encoded by integrons could be also present in many isolates. Moreover, our data are in line with earlier suggestions that acquisition of resistance determinants may not be a random process [38]. Initial acquisition of one or two important resistance genes might therefore act as a platform for acquiring more resistance genes. Chromosomal mutation in addition to plasmid acquisition or the presence of other integrons besides class 1 types could be associated with elevated antimicrobial resistance identified against other antimicrobials.

\section{Conclusion}

High resistance rates were identified in E. coli isolates in this study which occurs mainly through antibiotic resistance genes. These genes are present on mobile elements that could be transmitted to different pathogens. Similar integron components could be proved among strains of different clinical sources. It seems that imipenem can serve as drug of choice for treatment of multi resistant E. coli infections

\section{Acknowledgements}

All thanks and appreciation Department of Microbiology, Faculty of Medicine, Mansoura University, Egypt for providing clinical isolates of E. coli. This work was performed at Microbiology Department, Faculty of Pharmacy, Mansoura University, Egypt.

\section{Conflict of Interest}

The authors declare that they have no conflict of interest. 


\section{References}

[1] Yang, H., et al. (2004) Characterization of Multiple-Antimicrobial-Resistant Escherichia coli Isolates from Diseased Chickens and Swine in China. Journal of Clinical Microbiology, 42, 3483-3489. http://dx.doi.org/10.1128/JCM.42.8.3483-3489.2004

[2] Barlow, R.S., et al. (2004) Isolation and Characterization of Integron-Containing Bacteria without Antibiotic Selection. Antimicrob Agents Chemother, 48, 838-842. http://dx.doi.org/10.1128/AAC.48.3.838-842.2004

[3] Zanetti, M.O., et al. (2013) Antimicrobial Resistance, Plasmids and Class 1 and 2 Integrons Occurring in Pseudomonas aeruginosa Isolated from Brazilian Aquatic Environments. Water Science and Technology, 67, 1144-1149. http://dx.doi.org/10.2166/wst.2013.676

[4] Lu, L., et al. (2010) Characterization of Antimicrobial Resistance and Integrons among Escherichia coli Isolated from Animal Farms in Eastern China. Acta Tropica, 113, 20-25. http://dx.doi.org/10.1016/j.actatropica.2009.08.028

[5] Olsson-Liljequist, B., et al. (1997) Antimicrobial Susceptibility Testing in Sweden. III. Methodology for Susceptibility Testing. Scandinavian Journal of Infectious Diseases. Supplementum, 105, 13-23.

[6] Fluit, A. and Schmitz, F. (1999) Class 1 Integrons, Gene Cassettes, Mobility, and Epidemiology. European Journal of Clinical Microbiology \& Infectious Diseases, 18, 761-770. http://dx.doi.org/10.1007/s100960050398

[7] Lee, J.C., et al. (2001) The Prevalence of Trimethoprim-Resistance-Conferring Dihydrofolate Reductase Genes in Urinary Isolates of Escherichia coli in Korea. Journal of Antimicrobial Chemotherapy, 47, 599-604. http://dx.doi.org/10.1093/jac/47.5.599

[8] Nijssen, S., et al. (2005) Unnoticed Spread of Integron-Carrying Enterobacteriaceae in Intensive Care Units. Clinical Infectious Diseases, 41, 1-9. http://dx.doi.org/10.1086/430711

[9] Collis, C.M., et al. (2002) Integron-Encoded IntI Integrases Preferentially Recognize the Adjacent Cognate attI Site in Recombination with a 59-Be Site. Molecular Microbiology, 46, 1415-1427. http://dx.doi.org/10.1046/j.1365-2958.2002.03260.x

[10] Cambray, G., Guerout, A.M. and Mazel, D. (2010) Integrons. Annual Review of Genetics, 44, 141-166. http://dx.doi.org/10.1146/annurev-genet-102209-163504

[11] Navia, M.M., Ruiz, J. and Vila, J. (2004) Molecular Characterization of the Integrons in S higella Strains Isolated from Patients with Traveler's Diarrhea. Diagnostic Microbiology and Infectious Disease, 48, 175-179. http://dx.doi.org/10.1016/j.diagmicrobio.2003.10.007

[12] Mathai, E., Grape, M. and Kronvall, G. (2004) Integrons and Multidrug Resistance among Escherichia coli Causing Community-Acquired Urinary Tract Infection in Southern India. APMIS, 112, 159-164. http://dx.doi.org/10.1111/j.1600-0463.2004.apm1120301.x

[13] Rijavec, M., Erjavec, M.S., Avguštin, J.A., Reissbrodt, R., Fruth, A., Križan-Hergouth, V. and Žgur-Bertok, D. (2006) High Prevalence of Multidrug Resistance and Random Distribution of Mobile Genetic Elements among Uropathogenic Escherichia coli (UPEC) of the Four Major Phylogenetic Groups. Current Microbiology, 53, 158-162. http://dx.doi.org/10.1007/s00284-005-0501-4

[14] Yu, H.S., Lee, J.C., Kang, H.Y., Ro, D.W., Chung, J.Y., Jeong, Y.S., et al. (2003) Changes in Gene Cassettes of Class 1 Integrons among Escherichia coli Isolates from Urine Specimens Collected in Korea during the Last Two Decades. Journal of Clinical Microbiology, 41, 5429-5433. http://dx.doi.org/10.1128/JCM.41.12.5429-5433.2003

[15] Rao, A.N., Barlow, M., Clark, L.A., Boring, J.R., Tenover, F.C. and McGowan, J.E. (2006) Class 1 Integrons in Resistant Escherichia coli and Klebsiella spp., US Hospitals. Emerging Infectious Diseases, 12, 1011-1014. http://dx.doi.org/10.3201/eid1206.051596

[16] Ibrahim, M.E., Magzoub, M.A., Bilal, N.E. and Hamid, M.E. (2013) Distribution of Class I Integrons and Their Effect on the Prevalence of Multi-Drug Resistant Escherichia coli Clinical Isolates from Sudan. Saudi Medical Journal, 34, 240-247.

[17] Roe, M.T., Vega, E. and Pillai, S.D. (2003) Antimicrobial Resistance Markers of Class 1 and Class 2 Integron-Bearing Escherichia coli from Irrigation Water and Sediments. Emerging Infectious Diseases, 9, 822-826. http://dx.doi.org/10.3201/eid0907.020529

[18] Crichton, P. (1996) Enterobacteriaceae: Escherichia, Klebsiella, Proteus and Other Genera. In: Collee, J.G., Fraser, A.G., Marmion, B.P. and Simmons, A., Eds., Mckie and Maccarney Practical Medical Microbiology, 14th Edition, Churchill Living-Stone, Ebionburgh.

[19] NCCLS (2004) National Committee for Clinical Laboratory Standards. Performance Standards for Antimicrobial Disk and Dilution Susceptibility Tests for Bacteria: Approved Standard M31-A2. NCCLS, Wayne.

[20] Roe, M.T., Vega, E. and Pillai, S.D. (2003) Antimicrobial Resistance Markers of Class 1 and Class 2 Integron-Bearing Escherichia coli from Irrigation Water and Sediments. Emerging Infectious Diseases, 9, 822-826. 
[21] Ochman, H., Lawrence, J.G. and Groisman, E.A. (2000) Lateral Gene Transfer and the Nature of Bacterial Innovation. Nature, 405, 299-304.

[22] Hall, R.M. and Collis, C.M. (1998) Antibiotic Resistance in Gram-Negative Bacteria: The Role of Gene Cassettes and Integrons. Drug Resistance Updates, 1, 109-119. http://dx.doi.org/10.1016/S1368-7646(98)80026-5

[23] Japoni, A., Gudarzi, M., Farshad, S., Basiri, E., Ziyaeyan, M., Alborzi, A. and Rafaatpour, N. (2008) Assay for Integrons and Pattern of Antibiotic Resistance in Clinical Escherichia coli Strains by PCR-RFLP in Southern Iran. Japanese Journal of Infectious Diseases, 61, 85-88.

[24] Tariq, N., Jaffery, T., Ayub, R., Alam, A.Y., Javid, M.H. and Shafique, S. (2006) Frequency and Antimicrobial Susceptibility of Aerobic Bacterial Vaginal Isolates. Journal of the College of Physicians and Surgeons Pakistan, 16, 196199.

[25] Gulsun, S., Oguzoglu, N., Inan, A. and Ceran, N. (2005) The Virulence Factors and Antibiotic Sensitivities of Escherichia coli Isolated from Recurrent Urinary Tract Infections. Saudi Medical Journal, 26, 1755-1758.

[26] Sahm, D.F., Thornsberry, C., Mayfield, D.C., Jones, M.E. and Karlowsky, J.A. (2001) Multidrug-Resistant Urinary Tract Isolates of Escherichia coli: Prevalence and Patient Demographics in the United States in 2000. Antimicrobial Agents and Chemotherapy, 45, 1402-1406. http://dx.doi.org/10.1128/AAC.45.5.1402-1406.2001

[27] Mazel, D. (2006) Integrons: Agents of Bacterial Evolution. Nature Reviews Microbiology, 4, 608-620. http://dx.doi.org/10.1038/nrmicro1462

[28] Karczmarczyk, M., Walsh, C., Slowey, R., Leonard, N. and Fanning, S. (2011) Molecular Characterization of Multidrug-Resistant Escherichia coli Isolates from Irish Cattle Farms. Applied and Environmental Microbiology, 77, 71217127. http://dx.doi.org/10.1128/AEM.00601-11

[29] Leverstein-Van Hall, M.A., Pauuw, A., Box, A.T., Blok, H.E., Verhoef, J. and Fluit, A.C. (2002) Presence of IntegronAssociated Resistance in the Community Is Widespread and Contributes to Multidrug Resistance in the Hospital. Journal of Clinical Microbiology, 40, 3038-3040. http://dx.doi.org/10.1128/JCM.40.8.3038-3040.2002

[30] Gassama, A., Aidara-Kane, A., Chainier, D., Denis, F. and Ploy, M.C. (2004) Integron-Associated Antibiotic Resistance in Enteroaggregative and Enteroinvasive Escherichia coli. Microbial Drug Resistance, 10, 27-30. http://dx.doi.org/10.1089/107662904323047763

[31] Su, J.Y., Shi, L., Yang, L.S., Xiao, Z.H., Li, X.H. and Yamasaki, S. (2006) Analysis of Integrons in Clinical Isolates of Escherichia coli in China during the Last Six Years. FEMS Microbiology Letters, 254, 75-80. http://dx.doi.org/10.1111/j.1574-6968.2005.00025.x

[32] Zhang, H.M., Shi, L., Li, L., Guo, S.Y., Zhang, X.M., Yamasaki, S., et al. (2004) Identification and Characterization of Class 1 Integron Resistance Gene Cassettes among Salmonella Strains Isolated from Healthy Humans in China. Microbiology and Immunology, 48, 639-645. http://dx.doi.org/10.1111/j.1348-0421.2004.tb03473.x

[33] Chang, L.L., Chang, T.M. and Chang, C.Y. (2007) Variable Gene Cassette Patterns of Class 1 Integron-Associated DrugResistant Escherichia coli in Taiwan. Kaohsiung Journal of Medical Sciences, 23, 273-280. http://dx.doi.org/10.1016/S1607-551X(09)70409-7

[34] Kang, H.Y., Jeong, Y.S., Oh, J.Y., Tae, S.H., Choi, C.H., Moon, D.C., et al. (2005) Characterization of Antimicrobial Resistance and Class 1 Integrons Found in Escherichia coli Isolates from Humans and Animals in Korea. Journal of Antimicrobial Chemotherapy, 55, 639-644. http://dx.doi.org/10.1093/jac/dki076

[35] Lindstedt, B.A., Heir, E., Nygård, I. and Kapperud, G. (2003) Characterization of Class I Integrons in Clinical Strains of Salmonella enterica Subsp. enterica Serovars Typhimurium and Enteritidis from Norwegian Hospitals. Journal of Medical Microbiology, 52, 141-149. http://dx.doi.org/10.1099/jmm.0.04958-0

[36] Nógrády, N., Gadó, I., Tóth, A. and Pászti, J. (2005) Antibiotic Resistance and Class 1 Integron Patterns of Non-Typhoidal Human Salmonella Serotypes Isolated in Hungary in 2002 and 2003. International Journal of Antimicrobial Agents, 26, 126-132. http://dx.doi.org/10.1016/j.jjantimicag.2005.04.015

[37] Petersen, A., Guardabassi, L., Dalsgaard, A. and Olsen, J.E. (2000) Class I Integrons Containing a dhfrI Trimethoprim Resistance Gene Cassette in Aquatic Acinetobacter spp. FEMS Microbiology Letters, 182, 73-76. http://dx.doi.org/10.1111/j.1574-6968.2000.tb08876.x

[38] O’Brien, T.F. (2002) Emergence, Spread, and Environmental Effect of Antimicrobial Resistance: How Use of an Antimicrobial Anywhere Can Increase Resistance to Any Antimicrobial Anywhere Else. Clinical Infectious Diseases, 34, S78-S84. http://dx.doi.org/10.1086/340244 